\title{
Teachers' Attitude towards Using Songs in English Vocabulary Classes
}

\author{
Lana Hussain Ahmed Shahata \\ English Department, First Common Year, King Saud University - KSU \\ Tel: 966-537-303-120Ｅ-mail: lana.shehata@gmail.com
}

Received: June 14, 2020

Accepted: August 4, 2020

Published: November 15, 2020

doi:10.5296/gjes.v6i2.17977 URL: https://doi.org/10.5296/gjes.v6i2.17977

\begin{abstract}
This paper aims at identifying teachers' attitude towards using songs in English vocabulary classes. The study is descriptive in nature. It uses a sample of closely related group members; formed of teachers of English from different Sudanese schools. That group is made up of 35 teachers. The data collection tool used is a 5-point Likert scale questionnaire for the teachers. The data from the questionnaire are treated statistically by using SPSS program. The weighted means for the individual items and for the whole aspects of the tool are calculated. The results are used to answer the study questions and to verify the hypotheses. The study comes out with some important results that include (1) Teachers strongly agree that songs make the teaching English vocabulary classes fun, so they have positive attitudes towards using them. (2) There are many difficulties that face teachers in using songs in English vocabulary classes. The paper offers five recommendations concerning the following: (a) songs have to have their due weight in classroom practice. They have to be used more frequently. (b) Teachers should be trained on how to avoid the pitfalls of songs and they should be trained on how to maximize their benefits. (c) School administrations should be made aware of the importance of songs and they should provide more opportunities for the teachers to use them. (d) Class tests and continuous assessment have to include songs. (e) Parents should be educated on the value of songs as effective techniques for learning English. Songs should be a constant feature in the Parents Day. The paper also suggests three areas for further research. These include (a) the ability of songs to develop listening and speaking skills. (b) The potentiality of songs to develop cultural awareness. (c) The potentiality of songs to match the characteristics of the new generations (Alpha Gen in particular).
\end{abstract}

Keywords: Song, Attitude, Sentimental, Cognitive, Motivation, Memory 


\section{MlMacrothink}

\section{Introduction}

Songs have been part of the human experience for as long as we can remember. As Gugliemino (1986) stated, adults sing at religious services, bars, in the shower, and listening to the car radio. Songs have become an integral part of our language experience, and if used in coordination with a language lesson they can be of great value. Fortunately, with the expanding prevalence of the Internet and specifically the World Wide Web into both the classrooms and lives of students, access to music and lyrics has been made easier. This research focuses on the teachers' attitude for using songs by demonstrating students' effectiveness as a learning tool.

\subsection{Statement of the Problem}

Based on a fairly long experience of teaching English language at PYP Al-Majmaah University in the Kingdom of Saudi Arabia, the researcher observes that a considerable number of her students have a low level of achievement and that the teachers use a very limited set of tools and techniques during their lessons. For instance, "students, including L2 students, are often required to write theses and, as growing literature reveals, L2 students often experience difficulties in the four skills of this genre" (Bitchener \& Basturkmen, 2006, p. 4). Students who learn English as a foreign language also face some difficulties due to various reasons such as lack of interest in studying English, insufficient knowledge of four language skills, and limited exposure to inadequate teaching modern tools in classroom. The researcher asks herself some questions which kept recurring in the mind. Can modern tools be used in teaching English? Is it possible to use modern tools applicable in teaching all skills? Will modern tools be effective in teaching English as a foreign language and if so, how? These questions trigger a strong desire in the researcher's mind and encourage her to investigate this area of research.

\subsection{Questions of the Study}

1) What are teachers' attitudes towards the use of songs in teaching English vocabulary?

2) What are the difficulties that encounter the use of songs in English vocabulary?

\subsection{Hypothesis}

1) Teachers have positive attitude towards using songs in teaching English vocabulary classes.

2). There are some difficulties that encounter teachers in utilizing songs in teaching English vocabulary classes.

\subsection{Objectives of the Study}

1) To examine the general teachers' attitude towards to use of songs in teaching English vocabulary.

2) To discover the difficulties those encounter the use of songs in teaching. 


\subsection{Significance of the Study}

This study addresses one of the most important, but relatively neglected methods techniques of teaching using songs in classroom. It is intended to increase understanding of the effectiveness of classroom songs in English teaching as a foreign language. Furthermore, the study is pedagogically significant as it is expected to provide some recommendations about most effective English classroom songs teaching method and technique.

\section{Literature Review}

\subsection{Definition of Songs}

The well-known online encyclopedia Wikipedia cites song as a musical composition containing vocal parts and lyrics that are performed by the human voice, commonly accompanied by musical instruments. Popular songs contain any number of musical styles that are accessible to the general public and are distributed by one or more forms of mass media. This is in contrast to highbrow music, such as classical, which historically has always been the music of the elite and higher echelons of society, and traditional music which was normally disseminated orally. It is sometimes abbreviated to pop music and typically has a dance-along rhythm or beat, simple melodies and a repetitive structure, although pop music is more often used to describe a narrower branch of well-liked music. Moreover, Middleton (1990/2002, p. 139) stated that "While repetition is a feature of all songs and music of any sort, a high level of repetition may be a specific mark of "the popular songs", enabling an inclusive rather than exclusive audience". As a result, the unique characteristics of the music and songs; repeating composition, memorable lines or words, a catchy rhythm or beat, enable the language learners to memorize new words, as well as creating a pleasant ambiance motivating certain attitudes within the listeners. Songs utilization that allows learners to communicate widely and directly with other learners without time or place limitations has provided the language teaching field with many advantages such as increasing students' motivation, providing them with authentic material and allowing them to interact effectively in real and social contexts. Songs is one alternative way to improve English especially on vocabulary. Wrenshall (2002. p. 43) stated: "there is also plenty of evidence that songs help memorization, and the rhythm and rhyme of the lyrics can certainly help vocabulary as well."

According to (Peacock 1997, p. 51), "Songs also give students the opportunity to enrich vocabulary by vocalizing the language".

They are aurally and orally transmitted, they both contain phonetic, syntactic and semantic components and they develop early in life as social interactive media".

\subsection{Definition of Attitude}

'Attitude' refers to a favorable or unfavorable evaluative reaction by the teachers toward the use of English songs in the English teaching classroom. In psychological terms, attitude is a hypothetical construct that represents an individual's like or dislike of an item. According to Ajzen (1988), "attitude is the disposition by which one responds favorably or unfavorably to an object, person, institution, or event". Furthermore, Myers (1980, p. 36) defines "attitude as 
a favorable or unfavorable evaluative reaction toward something or someone". Attitudes, unlike physical characteristics or actions, cannot be directly observed or measured. Most of the time an individual's attitudes are hidden and can only emerge as reactions to specific stimuli in the form of stated beliefs, expressed feelings, or exhibited behaviors. Similarly, Baron and Byrne (1984, p. 126) define" attitude as long-term clusters of feelings, beliefs, and behavioral tendencies directed towards specific persons, ideas, objects or groups".

\subsection{Reasons for Using Songs in English Classroom}

\subsubsection{Sentimental Reason}

The Affective Filter Hypothesis is one of five proposed hypotheses developed by Steven Krashen. Basically, it is an explanation of how the affective factors relate to language learning. It is particularly appealing to teachers because it provides an explanation to why some learners learn and others do not.

Teachers have long recognized the need for students to have a positive attitude in regard to learning. Krashen (1982) explains that for optimal learning to occur the affective filter must be weak. A weak affective filter means that a positive attitude towards learning is present. If the affective filter is strong the learner will not seek language input, and in turn, not be open for language acquisition. The practical application of the Affective Filter Hypothesis is that teachers must provide a positive atmosphere conducive to language learning. Songs are one method for achieving a weak affective filter and promoting language learning. With the affective filter weak, Saricoban and Metin (2000) have found that songs can develop the four skill areas of reading, writing, listening, and speaking. Eken (1996, p.46) states that songs can be used:

- To present a topic, a language point, lexis, etc.

- To practice a language point, lexis, etc.

- To focus on common learner errors in a more direct way.

- To encourage extensive and intensive listening.

- To stimulate discussion of attitudes and feelings.

- To encourage creativity and use of imagination.

- To provide a relaxed classroom atmosphere.

- To bring variety and fun to learning.

Lo and Li (1998) stated that: learning English through songs develop a non-threatening classroom atmosphere in which four language skills can be enhanced. The belief that songs provide enjoyment and develop language skills is also noted by several other authors (Adamowski, 1997; Bechtold, 1983; Domoney \& Harris, 1993; Griffee, 1992; Guglielmino, 1986; Lems, 1984; Little, 1983; Monreal, 1982). The enjoyment aspect of learning language through song is directly related to affective factors 


\subsubsection{Cognitive Reasons}

Songs also present opportunities for developing automaticity which is the main cognitive reason for using songs in the classroom. Gatbonton and Segalowitz (1988, p. 473) define: "automaticity as a component of language fluency which involves both knowing what to say and producing language rapidly without pauses." Using songs can help automatize the language development process. Traditionally, it was believed that automatization would occur through repetitive exercises in a no communicative environment. However, the major shift towards the communicative teaching methodology requires that automatization occur in a different manner. Gatbonton and Segalowitz (1988, p. 476) stated that:

We must "place students in an environment in which it is appropriate to use target utterances in a genuinely communicative fashion." the nature of songs is fairly repetitive and consistent. For example, a song such as "Sailing" by Rod Stewart provides ample opportunities for students to focus on the present progressive tense. The repetitive style of the song lends itself to an activity in which students create their own present progressive sentences based upon their own interest. After listening to the song, students create their own lyrics following the same tune as the song. Lyrics such as: I am writing, I am writing, in my notebook with my friends, are common examples of the type of language that students produce.

\subsubsection{Verbal Reasons}

Besides automatization, there is also a linguistic reason for using songs in the classroom. Some songs are excellent examples of colloquial English, that is, the language of informal conversation. A song such as "My Best Was Never Good Enough" by Bruce Springsteen is a prime example of a song that demonstrates colloquial language use. This song is full of phrases like "Every cloud has a silver lining." and "Every dog has his day." Of course, the majority of language most ESL students will encounter is in fact informal. Using songs can prepare students for the genuine language they will be faced with. Finally, two studies, Domoney and Harris (1993) and Little (1983) investigated the prevalence of pop music in the lives of EFL students. They justified that music is often that major source of English outside of the classroom .The exposure to authentic English is an important factor in promoting language learning. It relates directly to both the affective filter and automaticity. If students are exposed to songs which they enjoy, more learning is likely to occur since they may seek out the music outside of the classroom. The repetitive style of songs then helps to promote automatization of colloquial language.

\subsection{Song Helps Learning}

Studies on songs have shown that it increases concentration, improves memory and decreases stress. Simply playing classical music in the background as you instruct or your students study will make a difference in their performance. And let's not forget that music is also one of the learning styles many of your students will possess, so including music in your classroom will help your students pay attention and remember the information you present. 


\subsection{Songs as a Motivation Source}

The notion of motivation is difficult to explain because "different people are motivated by different things" (House, 1997, p. 10). As House explains, children need to be motivated individually or within a group. By encouraging an individual child, the teacher stimulates and maintains interest in English. During this process teachers should be realistic about each individual student's abilities. Teachers also need to vary the group dynamics and in this way support the development of social interaction within a group of learners. In order to maintain positive motivation, these techniques should be planned in advance for each lesson. Motivation of young foreign language learners needs to be built gradually, making sure that the target structures are introduced in an easily attainable order. For this reason, songs serve as a perfect medium for achieving motivation. By using songs, children can get the feeling of success on an individual level, but also as being part of a group.

\subsection{Song and Memory}

As stated by Thornbury (2006), "There is no learning without memory, and language learning in particular, with the enormous load of vocabulary that it requires, is largely a memory task". Successful second language learning implies that learners can memorize the studied material and call on it whenever they need it while using the language. Several authors point out that music and songs can facilitate the long-term retention of the words, phrases and formulaic sequences that learners need to memorize Contemporary memory models differentiate between three components of memory:(1) Sensory memory, which captures the information in the environment detected by the sense organs and lets it go quickly if no attention is paid. (2) working memory, which has limited capacity and processes in the short term new information coming from an external source or old information recalled from long-term memory; and (3) long-term memory, which has enormous capacity and durability and stores information more permanently (Atkinson \& Shiffrin, 1968; Thornbury, 2006). It is usually necessary for information in working memory to be rehearsed for some time (silent mental repetition) so that it can move to long-term memory as a result of strengthening the memory trace. However, information should be frequently retrieved lest it decays and disappears (Thornbury, 2006). Thus, the key to storing material in long-term memory is rehearsal and retrieval. According to Calvert and Tart (1993), "songs present content in a form that may be easily stored, rehearsed, and retrieved.

As stated by Thornbury (2006), "There is no learning without memory, and language learning in particular, with the enormous load of vocabulary that it requires, is largely a memory task". Successful second language learning implies that learners can memorize the studied material and call on it whenever they need it while using the language. Several authors point out that music and songs can facilitate the long-term retention of the words, phrases and formulaic sequences that learners need to memorize Contemporary memory models differentiate between three components of memory:

(1) Sensory memory, which captures the information in the environment detected by the sense organs and lets it go quickly if no attention is paid. 
(2) working memory, which has limited capacity and processes in the short term new information coming from an external source or old information recalled from long-term memory; and (3) long-term memory, which has enormous capacity and durability and stores information more permanently (Atkinson \& Shiffrin, 1968; Thornbury, 2006). It is usually necessary for information in working memory to be rehearsed for some time (silent mental repetition) so that it can move to long-term memory as a result of strengthening the memory trace. However, information should be frequently retrieved lest it decays and disappears (Thornbury, 2006). Thus, the key to storing material in long-term memory is rehearsal and retrieval. According to Calvert and Tart (1993), "songs present content in a form that may be easily stored, rehearsed, and retrieved

As stated by Thornbury (2006), "There is no learning without memory, and language learning in particular, with the enormous load of vocabulary that it requires, is largely a memory task". Successful second language learning implies that learners can memorize the studied material and call on it whenever they need it while using the language. Several authors point out that music and songs can facilitate the long-term retention of the words, phrases and formulaic sequences that learners need to memorize Contemporary memory models differentiate between three components of memory: (1) Sensory memory, which captures the information in the environment detected by the sense organs and lets it go quickly if no attention is paid.(2) working memory, which has limited capacity and processes in the short term new information coming from an external source or old information recalled from long-term memory; and (3) long-term memory, which has enormous capacity and durability and stores information more permanently (Atkinson \& Shiffrin, 1968; Thornbury, 2006). It is usually necessary for information in working memory to be rehearsed for some time (silent mental repetition) so that it can move to long-term memory as a result of strengthening the memory trace. However, information should be frequently retrieved lest it decays and disappears (Thornbury, 2006). Thus, the key to storing material in long-term memory is rehearsal and retrieval. According to Calvert and Tart (1993), "songs present content in a form that may be easily stored, rehearsed, and retrieved.

\subsection{Advantages of Using Songs}

Language teachers can and should use songs as part of their classroom teaching repertoire. Songs contain authentic language, are easily obtainable, provide vocabulary, and are fun for the students.

1) Songs almost always contains authentic, natural language.

2) A variety of new vocabulary can be introduced to students through songs.

3) Songs are usually very easily obtainable.

4) Songs can be selected to suit the needs and interests of the students.

5) Vocabulary can be introduced through songs.

6) Time length is easily controlled. 
7) Students can experience a wide range of accents.

8) Students think songs are natural and fun.

\subsection{Previous Studies}

(1) Mustafa Sevik (2011). Teacher views about using songs in teaching English to young learners. The primary aim of this study was to explore the views of Turkish state primary school EFL teachers about songs and using songs in teaching English to young learners. English language teachers' $(n=52)$ opinions were collected through a questionnaire and the results demonstrated that Turkish EFL teachers have strong beliefs about the pedagogical value of songs and about the effectiveness of using songs in teaching EFL to young learners. However, findings showed that teachers had difficulty in accessing to appropriate songs to use in their classes and in measuring student success when they use songs. Therefore it was suggested in this study that teachers be provided with song materials to use in their classes. Measuring student success was closely related to how to teach songs, and therefore it was suggested that teachers be given in-service training about how to teach songs. To conclude, we may argue that the findings of this study strengthened previous research findings about the role of songs in teaching English to young learners.

(2) Nihada Delibegovic (2016) the effect of using songs on young learners and their motivation of learning English. Songs are appreciated for their linguistic, pedagogical, cultural and entertaining features and they are precious language learning materials. They can be used to teach and develop every aspect of a language. This paper aims to verify these claims and confirm the effectiveness of using songs as a means to improve young learners' English language vocabulary and to determine whether songs influence young learners' motivation to learn English. The paper deals with theoretical explanations of young learners, listening skills, and different aspects of using and teaching songs. It also discusses how songs influence motivation and the connection of songs with some language learning theories. The analytical part of the paper explains the procedure and the results obtained from the pre-tests, post-tests and delayed tests for three different children's songs as well as from the questionnaire that was done in order to collect information about motivation provided by songs. The results showed that songs have a positive influence on vocabulary retention of young learners. Whatever setting is used, aural or aural/visual, the results prove that songs are suitable for different learning styles; they encourage positive learning experience, and enhance their knowledge. Songs aid motivation and help learners develop a love for language learning. Students motivated in this way are imaginative, creative, and eager to learn and succeed.

(3) Mohammed A. A. Farrah (2016) the effectiveness of using children's songs in developing elementary grades' English vocabulary and pronunciation in Jerusalem, Palestine. This study aimed at investigating the effect of using children's songs in developing the elementary graders' vocabulary and pronunciation. It aimed also to investigate teachers' attitudes towards the use of songs in their English classes. The participants were 123 EFL students of the fourth grade; 72 females and 51 males. Arabic is their native language. Both groups are from four private schools in Jerusalem; two groups for boys, and two groups for girls. One boys' school 
and one girls' school were chosen to be the experimental group consisting of 58 participants, while the other boys' and girls' schools were chosen to be the control group consisting of 65 participants. Study data were collected via students' pre and post tests and teachers' questionnaire. Exams results showed that students have improved their vocabulary and pronunciation due to the use of songs in learning. Questionnaire results showed that teachers have positive attitudes towards the use of songs in their classes as songs have positive effects in increasing students' achievement, interest and motivation. Finally, results revealed that students' achievements were not affected by gender.

\section{The Methodology}

This study followed a descriptive method. A questionnaire was given to the teachers for the purpose of having their opinions on the songs. This is the first research Instrument for collecting relevant data and information and both the validity and reliability of the research will be confirmed.

\subsection{Sample of the Study}

The study was conducted in Saudi Arabia Majmaah University. A purposive sample was used for this study which includes (35) respondents from different English college teachers in Majmaah University.

\section{Data Collection Tool}

The researcher used a questionnaire as an instrument for data collection and relevant information for this study. The questionnaire was designed to teacher's attitude towards using songs in English vocabulary classes. The questionnaire was distributed to (35) participants of English teachers to gather their perceptions and views on the English language teaching.13, D

Hypothesis (1): Teachers have positive attitude towards using songs in teaching English vocabulary classes.

Statement No (1): Songs can enhance students' memories and improve their learning vocabulary.

Table 1. The frequency distribution for the respondents' answers of statement No (1)

\begin{tabular}{|c|c|c|}
\hline Valid & Frequency & Percentage \\
\hline Strongly agree & 19 & 54.2 \\
\hline Agree & 15 & 42.8 \\
\hline Neutral & 1 & 3.0 \\
\hline Disagree & 0 & 0 \\
\hline Strongly Disagree & 0 & 0 \\
\hline Total & 35 & 100 \\
\hline
\end{tabular}




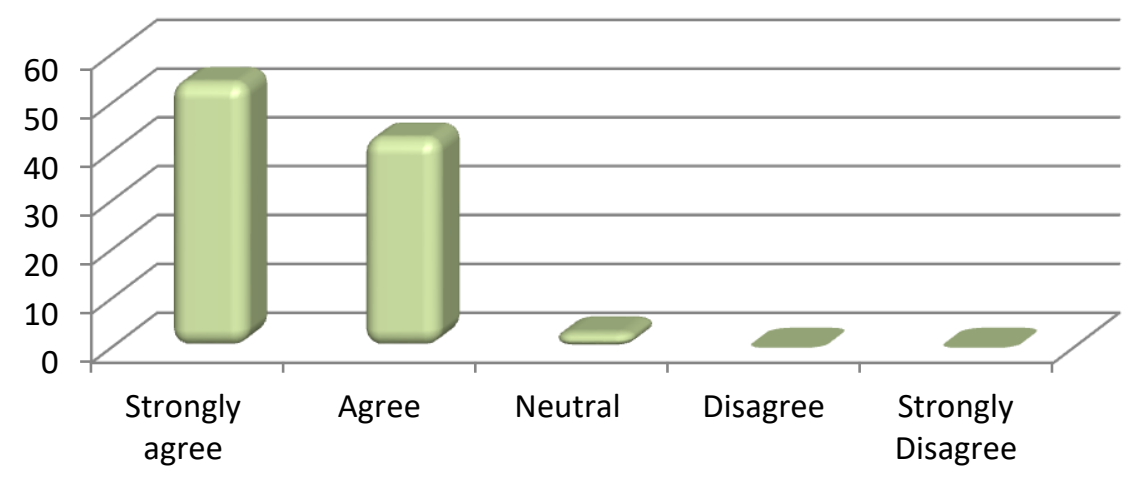

Figure 1. The frequency distribution for the respondents' answers of statement No (1)

From the above table 1 and figure 1, It is clear that there are (19) persons in the study's sample with percentage (54.2\%) strongly agreed with "Songs can enhance students' memories and improve their learning vocabulary". There are (15) persons with percentage $(42.8 \%)$ agreed with that, and (1) persons with percentage (13.3\%) was neutral. and (0) persons with percentage $(0 \%)$ disagreed and $(0)$ persons with $(0 \%)$ are strongly disagreed.

Statement No (2): Using songs in the classroom makes teaching and learning English more interesting.

Table 2. The frequency distribution for the respondents' answers of statement No. (2)

\begin{tabular}{|c|c|c|}
\hline Valid & Frequency & Percentage \\
\hline Strongly agree & 18 & 51.3 \\
\hline Agree & 16 & 45.7 \\
\hline Neutral & 1 & 3.0 \\
\hline Disagree & 0 & 0 \\
\hline Strongly Disagree & 0 & 0 \\
\hline Total & 35 & 100 \\
\hline
\end{tabular}

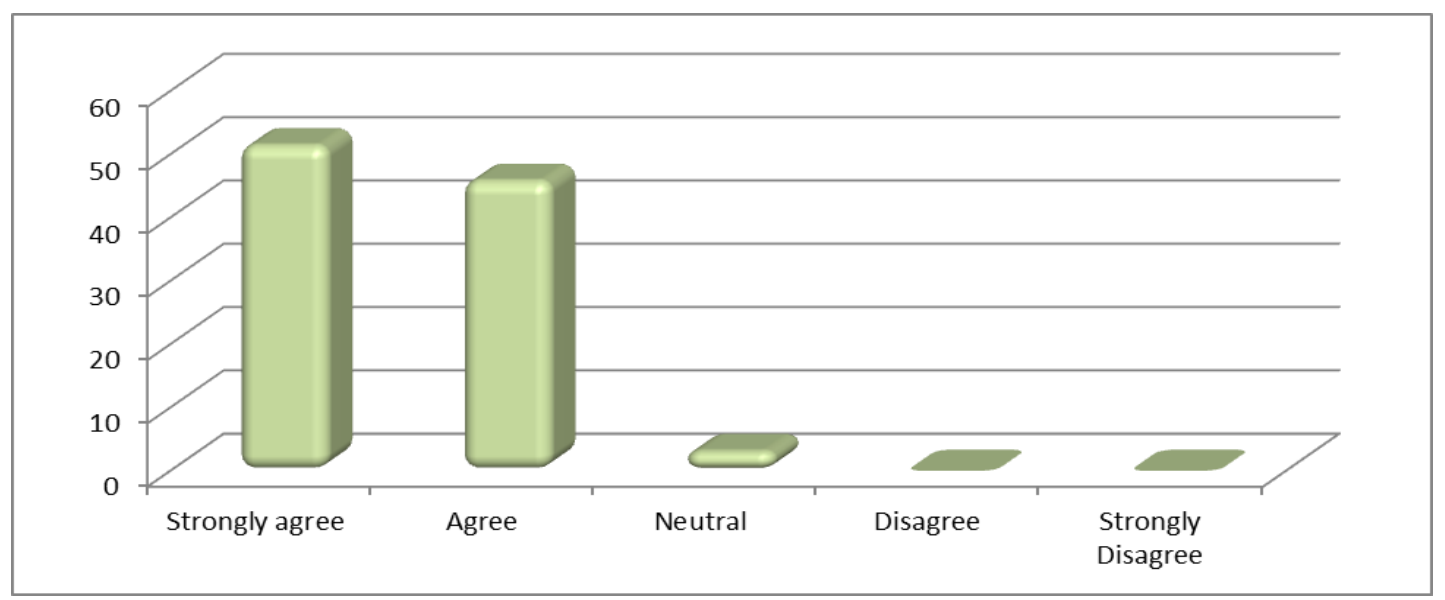

Figure 2. The frequency distribution for the respondents' answers of statement No. (2) 
From the above table 2 and figure 2 It is clear that there are (18) persons in the study's sample with percentage $(51.3 \%)$ strongly agreed with "Using songs in the classroom makes teaching and learning English more interesting. There are (16) persons with percentage (45.7\%) agreed with that, and (1) persons with percentage (3.0\%) was neutral. and (0) persons with percentage $(0 \%)$.

Statement No (3): Using songs in teaching vocabulary motivates learners.

Table 3. The frequency distribution for the respondents' answers of statement No. (3)

\begin{tabular}{|c|c|c|}
\hline Valid & Frequency & Percentage \\
\hline Strongly agree & 15 & 42.8 \\
\hline Agree & 18 & 51.2 \\
\hline Neutral & 2 & 6.0 \\
\hline Disagree & 0 & 0 \\
\hline Strongly Disagree & 0 & 0 \\
\hline Total & 35 & 100 \\
\hline
\end{tabular}

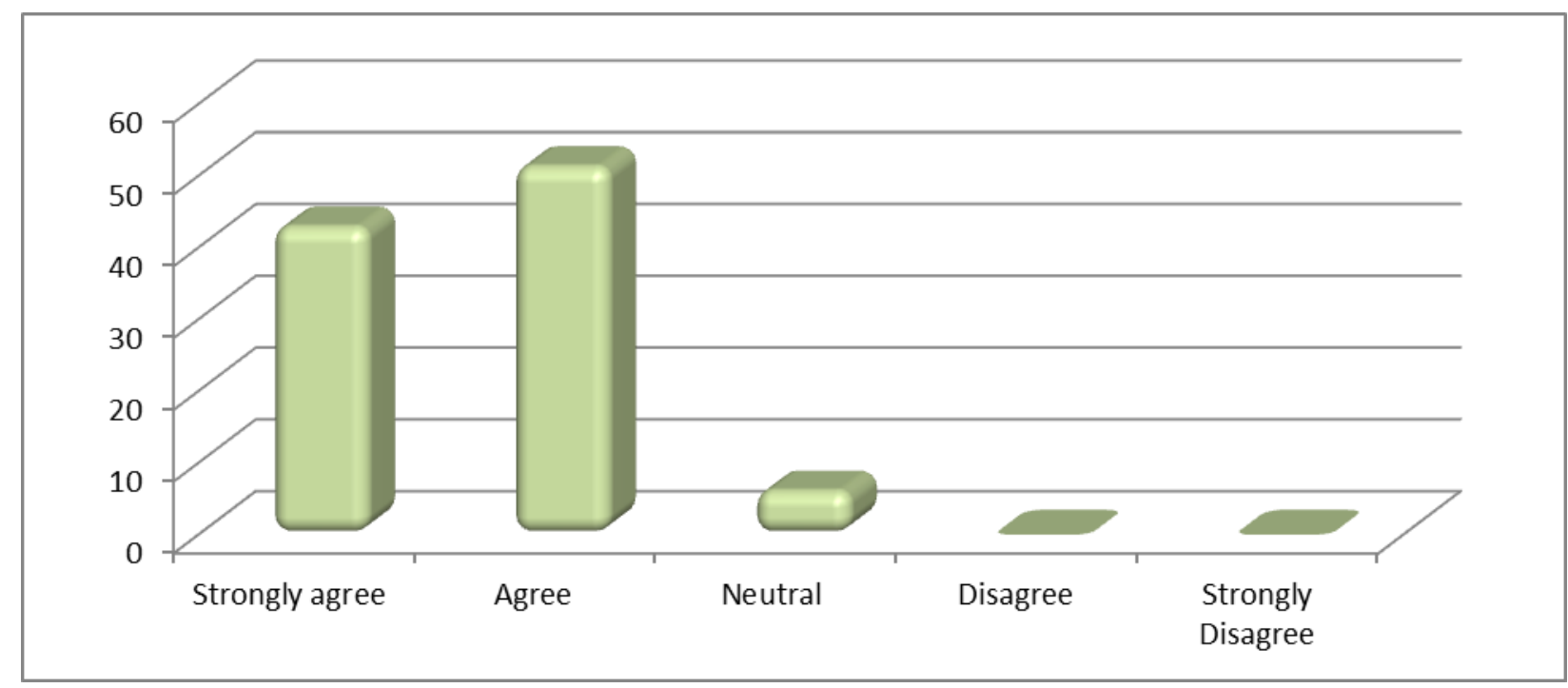

Figure 3. The frequency distribution for the respondents' answers of statement No. (3)

From the above table 3 and figure 3 It is clear that there are (15) persons in the study's sample with percentage $(42.8 \%)$ strongly agreed with "Using songs in teaching vocabulary motivates learners." There are (18) persons with percentage (51.2\%) agreed with that, and (2) persons with percentage $(6.0 \%)$ was neutral. and $(0)$ persons with percentage $(0 \%)$ disagreed and $(0)$ persons with $(0 \%)$ are strongly disagreed. Disagreed and $(0)$ persons with $(0 \%)$ are strongly disagreed.

Statement No (4): Using songs can decrease students' anxiety about English vocabulary. 
Table 4. The frequency distribution for the respondents' answers of statement no. (4)

\begin{tabular}{|c|c|c|}
\hline Valid & Frequency & Percentage \\
\hline Strongly agree & 19 & 54.0 \\
\hline Agree & 12 & 34.0 \\
\hline Neutral & 3 & 9.0 \\
\hline Disagree & 1 & 3.0 \\
\hline Strongly Disagree & 0 & 0 \\
\hline Total & 35 & 100 \\
\hline
\end{tabular}

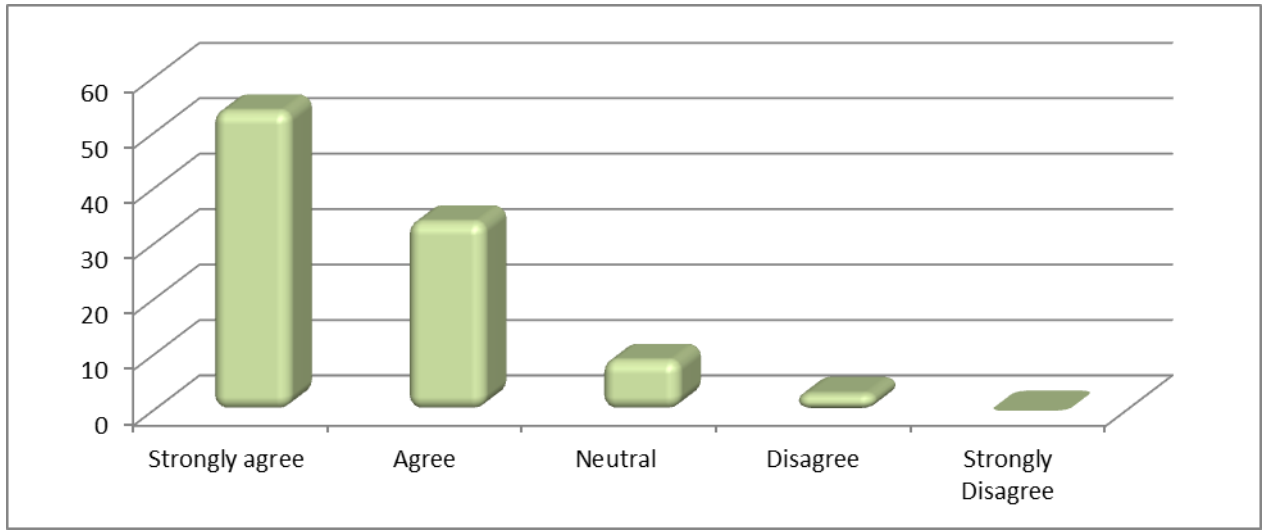

Figure 4. The frequency distribution for the respondents' answers of statement no. (4)

From the above table 4 and figure 4, It is clear that there are (19) persons in the study's sample with percentage (54.0\%) strongly agreed with "Using songs can decrease students' anxiety about English vocabulary." There are (12) persons with percentage (34.0\%) agreed with that, and (3) persons with percentage $(9.0 \%)$ was neutral. and (1) persons with percentage $(3 \%)$ disagreed and $(0)$ persons with $(0 \%)$ are strongly disagreed.

Statement No (5): Students use new words and phrases outside classroom.

Table 5. The frequency distribution for the respondents' answers of statement no. (5)

\begin{tabular}{|c|c|c|}
\hline Valid & Frequency & Percentage \\
\hline Strongly agree & 9 & 25.7 \\
\hline Agree & 19 & 54.3 \\
\hline Neutral & 7 & 20.0 \\
\hline Disagree & 0 & 0 \\
\hline Strongly Disagree & 0 & 0 \\
\hline Total & 35 & 100 \\
\hline
\end{tabular}




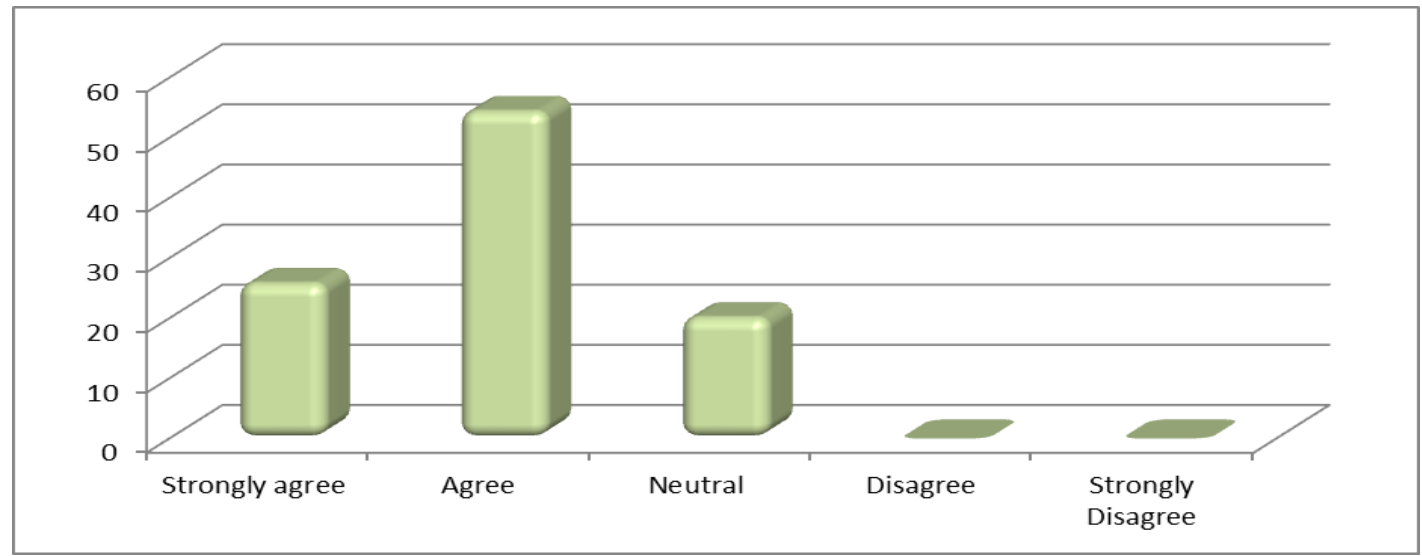

Figure 5. The frequency distribution for the respondents' answers of statement no. (5)

From the above table 5 and figure 5, It is clear that there are (9) persons in the study's sample with percentage $(25.7 \%)$ strongly agreed with "Students use new words and phrases outside classroom. "There are (19) persons with percentage (54.3\%) agreed with that, and (7) persons with percentage $(20.0 \%)$ was neutral. and $(0)$ persons with percentage $(0 \%)$ disagreed and $(0)$ persons with (0\%) are strongly disagreed.

Statement No (6): Songs provide a large amount of repetition which results in automatic use of the target language.

Table 6. The frequency distribution for the respondents' answers of statement no. (6)

\begin{tabular}{|c|c|c|}
\hline Valid & Frequency & Percentage \\
\hline Strongly agree & 15 & 42.8 \\
\hline Agree & 15 & 42.8 \\
\hline Neutral & 4 & 11.4 \\
\hline Disagree & 1 & 3.0 \\
\hline Strongly Disagree & 0 & 0 \\
\hline Total & 35 & 100 \\
\hline
\end{tabular}

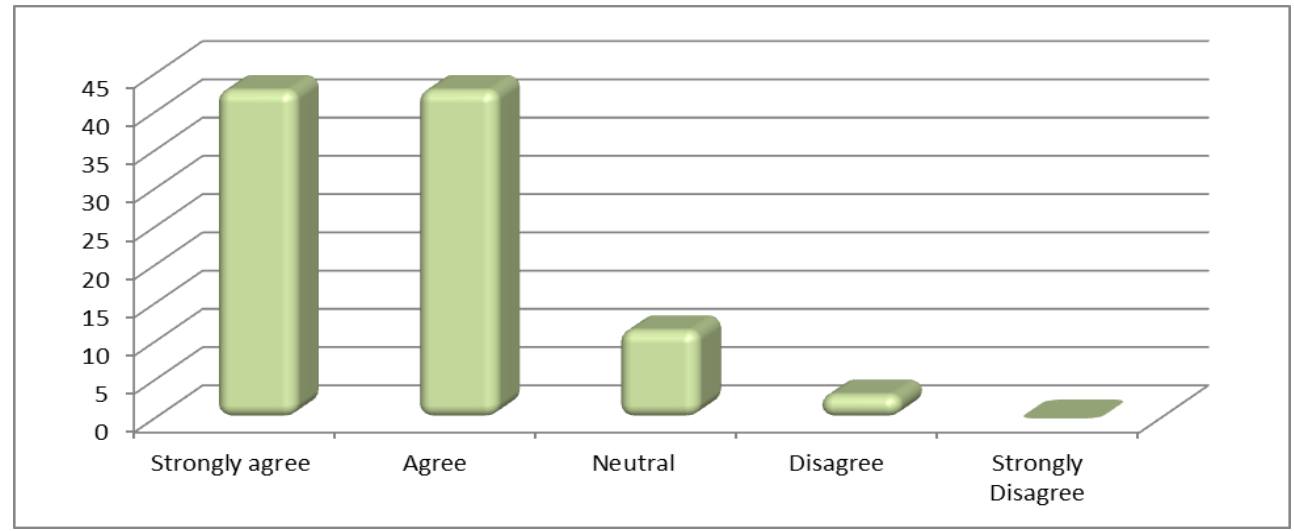

Figure 6. The frequency distribution for the respondents' answers of statement no. (6) 


\section{NI Macrothink}

Global Journal of Educational Studies

ISSN 2377-3936

2020, Vol. 6, No. 2

From the above table 6 and figure 6, It is clear that there are (15) persons in the study's sample with percentage (42.8\%) strongly agreed with "Songs provide a large amount of repetition which results in automatic use of the target language. "There are (15) persons with percentage $(42.8 \%)$ agreed with that, and (4) persons with percentage (11.4\%) was neutral. and (1) persons with percentage (3\%) disagreed and (0) persons with $(0 \%)$ are strongly disagreed.

Statement No (7): Students prefer songs being incorporated as a part of the lesson.

Table 7. The frequency distribution for the respondents' answers of statement No. (7)

\begin{tabular}{|c|c|c|}
\hline Valid & Frequency & Percentage \\
\hline Strongly agree & 8 & 22.8 \\
\hline Agree & 16 & 45.7 \\
\hline Neutral & 10 & 28.5 \\
\hline Disagree & 1 & 3.0 \\
\hline Strongly Disagree & 0 & 0 \\
\hline Total & 35 & 100 \\
\hline
\end{tabular}

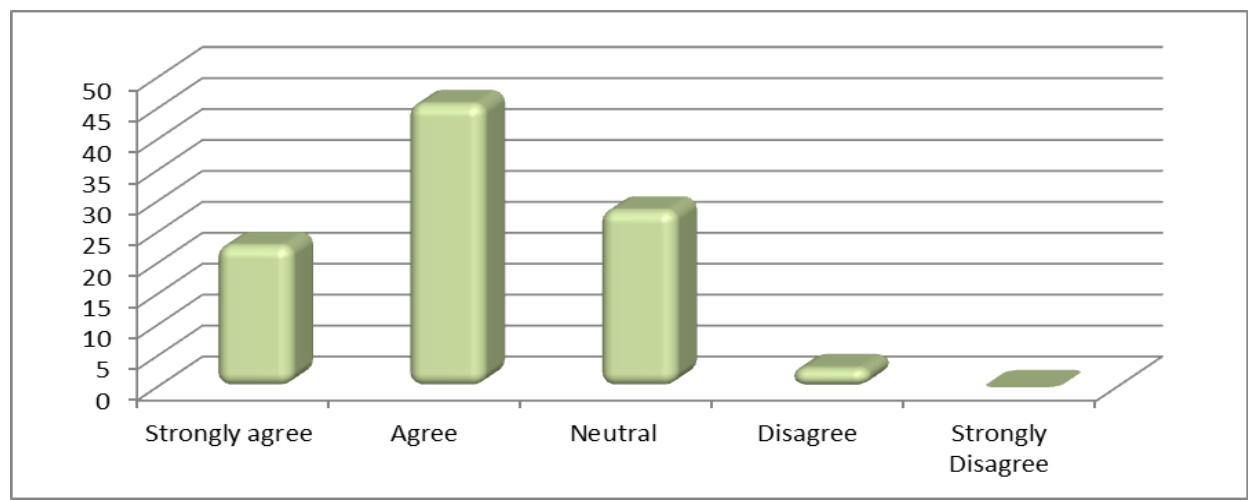

Figure 7. The frequency distribution for the respondents' answers of statement No. (7)

From the above table 7 and figure 7, It is clear that there are (8) persons in the study's sample with percentage $(22.8 \%)$ strongly agreed with "Students prefer songs being incorporated as a part of the lesson." There are (16) persons with percentage (45.7\%) agreed with that, and (10) persons with percentage $(28.5 \%)$ was neutral. and (1) persons with percentage $(3.0 \%)$ disagreed and (0) persons with $(0 \%)$ are strongly disagreed.

Hypothesis (2): There are some difficulties that teachers encounter in utilizing songs in teaching English vocabulary.

Statement No (8): I assume that students use the vocabulary lesson of songs after repeating them several times. 
Table 8. The frequency distribution for the respondents' answers of statement No. (8)

\begin{tabular}{|c|c|c|}
\hline Valid & Frequency & Percentage \\
\hline Strongly agree & 9 & 25.7 \\
\hline Agree & 21 & 60.0 \\
\hline Neutral & 5 & 14.3 \\
\hline Disagree & 0 & 0 \\
\hline Strongly Disagree & 0 & 0 \\
\hline Total & 35 & 100 \\
\hline
\end{tabular}

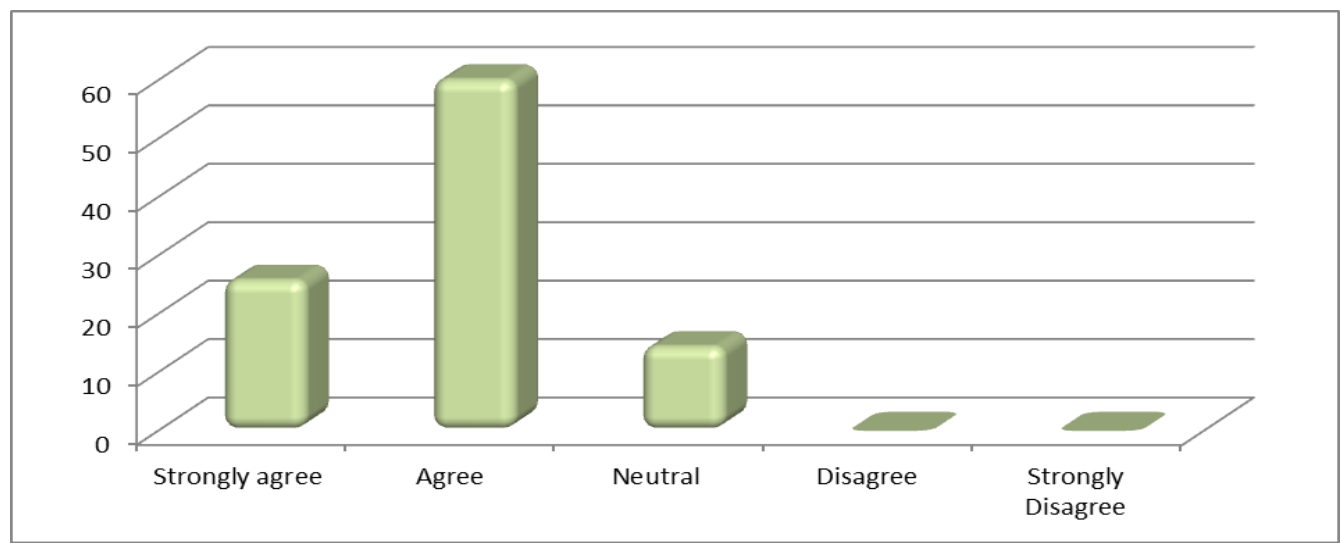

Figure 8. The frequency distribution for the respondents' answers of statement No. (8)

From the above table 8 and figure 8, It is clear that there are (9) persons in the study's sample with percentage (25.7\%) strongly agreed with "I assume that students use the vocabulary lesson of songs after repeating them several times.". There are (21) persons with percentage $(60.0 \%)$ agreed with that, and (5) persons with percentage (14.3\%) was neutral. and (0) persons with percentage $(0 \%)$ disagreed and (0) persons with $(0 \%)$ are strongly disagreed.

Statement No (9): It is difficult to choose an appropriate song for every topic of the English vocabulary.

Table 9. The frequency distribution for the respondents' answers of statement No. (9)

\begin{tabular}{|c|c|c|}
\hline Valid & Frequency & Percentage \\
\hline Strongly agree & 13 & 37.0 \\
\hline Agree & 15 & 42.8 \\
\hline Neutral & 5 & 14.2 \\
\hline Disagree & 1 & 3.0 \\
\hline Strongly Disagree & 1 & 0 \\
\hline Total & 35 & 100 \\
\hline
\end{tabular}




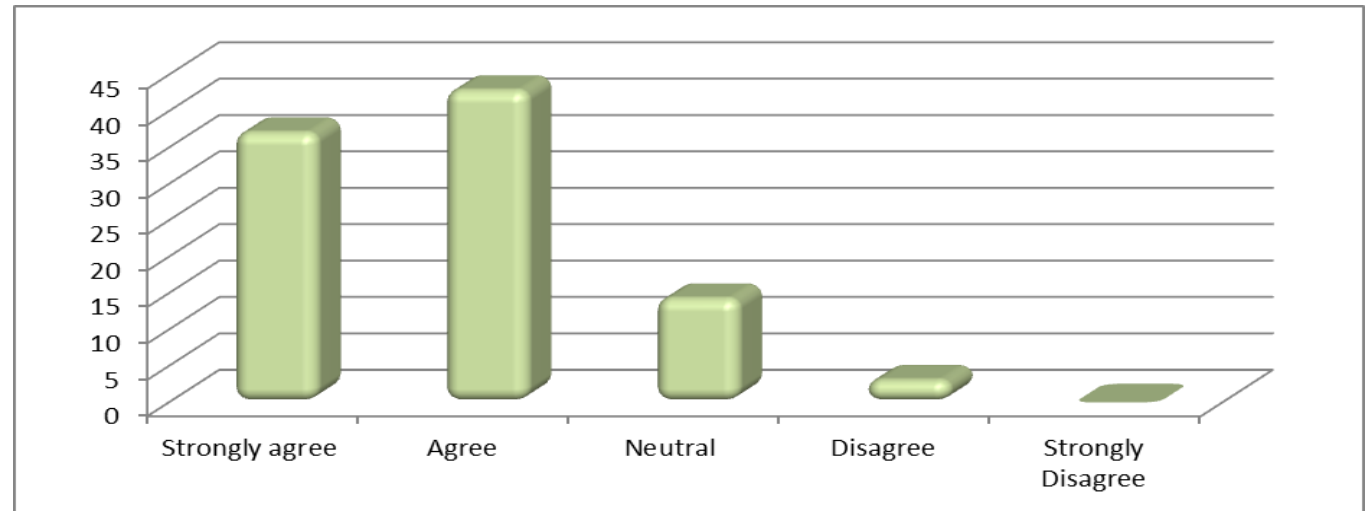

Figure 9. The frequency distribution for the respondents' answers of statement No. (9)

From the above table 9 and figure 9, It is clear that there are (13) persons in the study's sample with percentage (37.0\%) strongly agreed with "It is difficult to choose an appropriate song for every topic of the English vocabulary." There are (15) persons with percentage $(42.8 \%)$ agreed with that, and (5) persons with percentage $(14.2 \%)$ was neutral. and (1) persons with percentage (3.0\%) disagreed and (1) persons with $(3.0 \%)$ are strongly disagreed.

Statement No (10): I face some difficulties in applying songs in my class.

Table 10. The frequency distribution for the respondents' answers of statement no. (10)

\begin{tabular}{|c|c|c|}
\hline Valid & Frequency & Percentage \\
\hline Strongly agree & 4 & 11.0 \\
\hline Agree & 9 & 25.7 \\
\hline Neutral & 18 & 51.3 \\
\hline Disagree & 3 & 9.0 \\
\hline Strongly Disagree & 1 & 3.0 \\
\hline Total & 35 & 100 \\
\hline
\end{tabular}

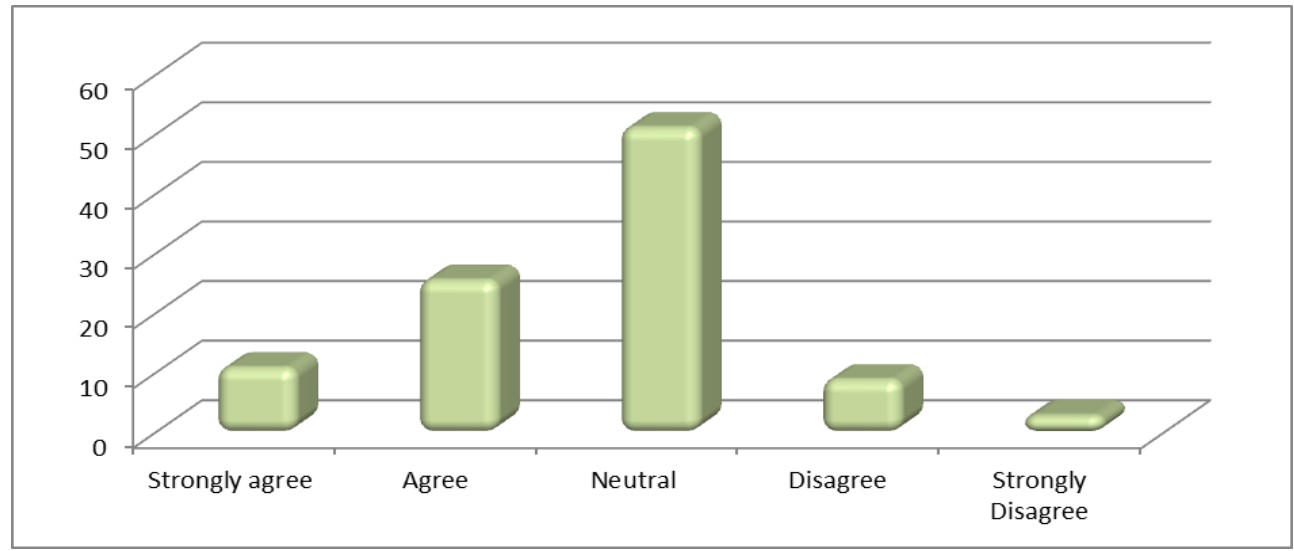

Figure 10. The frequency distribution for the respondents' answers of statement no. (10) 
From the above table 10 and figure 10 It is clear that there are (4) persons in the study's sample with percentage (11.0\%) strongly agreed with "I face some difficulties in applying songs in my class." There are (9) persons with percentage (25.7\%) agreed with that, and (18) persons with percentage $(51.3 \%)$ was neutral. and (3) persons with percentage (9\%) disagreed and (1) persons with (3\%) are strongly disagreed.

Table 11. Chi -Square Test for Hypothesis NO. (1): Teachers have positive attitude towards using songs in teaching English vocabulary classes

\begin{tabular}{|c|c|c|c|c|c|}
\hline No & Statement & Mean & SD & Chi square & p-value \\
\hline 1 & $\begin{array}{l}\text { Songs can enhance students' memories and improve } \\
\text { their learning vocabulary. }\end{array}$ & 2.7 & 4.1 & 22 & 0.000 \\
\hline 2 & $\begin{array}{l}\text { Using songs in the classroom makes teaching and } \\
\text { learning English more interesting. }\end{array}$ & 2.6 & 0.5 & 19 & 0.000 \\
\hline 3 & Using songs in teaching vocabulary motivates learners. & 2.5 & 0.9 & 31 & 0.000 \\
\hline 4 & $\begin{array}{l}\text { Using songs can decrease students' anxiety about } \\
\text { English vocabulary. }\end{array}$ & 2.9 & 1.6 & 22 & 0.000 \\
\hline 5 & Students use new words and phrases outside classroom. & 2.8 & 2.1 & 27 & 0.000 \\
\hline 6 & $\begin{array}{l}\text { Songs provide a large amount of repetition which } \\
\text { results in automatic use of the target language. }\end{array}$ & 2.7 & 1.5 & 29 & 0.000 \\
\hline 7 & $\begin{array}{l}\text { Students prefer songs being incorporated as a part of the } \\
\text { lesson. }\end{array}$ & 2.6 & 0.5 & 34 & 0.000 \\
\hline \multicolumn{6}{|c|}{$\begin{array}{l}\text { There are some difficulties that teachers encounter in utilizing songs in teaching English } \\
\text { vocabulary. }\end{array}$} \\
\hline 8 & $\begin{array}{l}\text { I assume that students use the vocabulary lesson of } \\
\text { songs after repeating them several times. }\end{array}$ & 2.4 & 1.6 & 27 & 0.000 \\
\hline 9 & $\begin{array}{l}\text { It is difficult to choose an appropriate song for every } \\
\text { topic of the English vocabulary. }\end{array}$ & 2.7 & 4.1 & 22 & 0.000 \\
\hline 10 & I face some difficulties in applying songs in my class. & 2.6 & 0.5 & 19 & 0.000 \\
\hline
\end{tabular}

The calculated value of chi-square for the significance of the differences for the respondent's responses in the 1st statement was (22) which is greater than the tabulated value of chi-square at the degree of freedom (4) and the significant value level (5\%) which was (11.7). This indicates that, there are statistically significant differences at the level (5\%) among the responses of the respondents, and also the calculated mean is (2.8) which is greater than the hypothesized mean (2.3) which supports the respondents who disagreed with the statement "Songs can enhance students' memories and improve their learning vocabulary.

The calculated value of chi-square for the significance of the differences for the respondent's responses in the 2nd statement was (19) which is greater than the tabulated value of chi-square at the degree of freedom (4) and the significant value level (5\%) which was (11.7). This indicates that, there are statistically significant differences at the level (5\%) among the responses of the respondents, and also the calculated mean is (2.6) which is greater than the 
hypothesized mean (2.3) which supports the respondents who disagreed with the statement "Using songs in the classroom makes teaching and learning English more interesting.."

The calculated value of chi-square for the significance of the differences for the respondent's responses in the 3rd statement was (31) which is greater than the tabulated value of chi-square at the degree of freedom (4) and the significant value level (5\%) which was (11.7). This indicates that, there are statistically significant differences at the level (5\%) among the responses of the respondents, and also the calculated mean is (2.5) which is greater than the hypothesized mean (2.3) which supports the respondents who disagreed with the statement "Using songs in teaching vocabulary motivates learners...."

The calculated value of chi-square for the significance of the differences for the respondent's responses in the 4th statement was (22) which is greater than the tabulated value of chi-square at the degree of freedom (4) and the significant value level (5\%) which was (11.7). This indicates that, there are statistically significant differences at the level (5\%) among the responses of the respondents, and also the calculated mean is (2.9) which is greater than the hypothesized mean (2.3) which supports the respondents who disagreed with the statement "Using songs can decrease students' anxiety about English vocabulary.

The calculated value of chi-square for the significance of the differences for the respondent's responses in the 5th statement was (27) which is greater than the tabulated value of chi-square at the degree of freedom (4) and the significant value level (5\%) which was (11.7). This indicates that, there are statistically significant differences at the level (5\%) among the responses of the respondents, and also the calculated mean is (2.8) which is greater than the hypothesized mean (2.3) which supports the respondents who disagreed with the statement "Students use new words and phrases outside classroom.

The calculated value of chi-square for the significance of the differences for the respondent's responses in the 6th statement was (29) which is greater than the tabulated value of chi-square at the degree of freedom (4) and the significant value level (5\%) which was (11.7). This indicates that, there are statistically significant differences at the level (5\%) among the responses of the respondents, and also the calculated mean is (2.7) which is greater than the hypothesized mean (2.3) which supports the respondents who disagreed with the statement "Songs provide a large amount of repetition which results in automatic use of the target language.

The calculated value of chi-square for the significance of the differences for the respondent's responses in the 7th statement was (34) which is greater than the tabulated value of chi-square at the degree of freedom (4) and the significant value level (5\%) which was (11.7). This indicates that, there are statistically significant differences at the level (5\%) among the responses of the respondents, and also the calculated mean is (2.6) which is greater than the hypothesized mean (2.3) which supports the respondents who disagreed with the statement "Students prefer songs being incorporated as a part of the lesson.

The calculated value of chi-square for the significance of the differences for the respondent's responses in the 8th statement was (27) which is greater than the tabulated value of 
chi-square at the degree of freedom (4) and the significant value level (5\%) which was (11.7). This indicates that, there are statistically significant differences at the level (5\%) among the responses of the respondents, and also the calculated mean is (2.4) which is greater than the hypothesized mean (2.3) which supports the respondents who disagreed with the statement "I assume that students use the vocabulary lesson of songs after repeating them several times..

The calculated value of chi-square for the significance of the differences for the respondent's responses in the 9th statement was (22) which is greater than the tabulated value of chi-square at the degree of freedom (4) and the significant value level (5\%) which was (11.7). This indicates that, there are statistically significant differences at the level (5\%) among the responses of the respondents, and also the calculated mean is (2.8) which is greater than the hypothesized mean (2.3) which supports the respondents who disagreed with the statement "It is difficult to choose an appropriate song for every topic of the English vocabulary.

The calculated value of chi-square for the significance of the differences for the respondent's responses in the 10th statement was (19) which is greater than the tabulated value of chi-square at the degree of freedom (4) and the significant value level (5\%) which was (11.7). This indicates that, there are statistically significant differences at the level (5\%) among the responses of the respondents, and also the calculated mean is (2.6) which is greater than the hypothesized mean (2.3) which supports the respondents who disagreed with the statement "I face some difficulties in applying songs in my class. According to the previous results it's obvious that the hypotheses of this study are accepted.

\section{Findings}

Although teachers strongly agree that songs make the teaching vocabulary classes language fun, they have positive attitudes towards using them. They think that songs:

1) May lead to controllable fun among the pupils.

2) May be suitable for the large classes.

3) May shift the attention of the pupils away from the language focus.

4) May be relevant to the learners' needs.

5) May encourage the use of correct language.

There are many difficulties that face teachers in using songs in English vocabulary classes. Some of these are:

6) Songs consume a lot of time. This will be at the expense of explaining the language material in question.

7) The school administration does normally welcome the using of songs in English vocabulary classes.

8) Some pupils do not feel at ease when songs are used in the English vocabulary classes.

9) It is not easy for teachers to integrate the four skills in songs. 


\subsection{Recommendations}

This study offers the following recommendations:

(1) Songs have to have their due weight in classroom practice. They have to be used more frequently.

(2) Teachers should be trained on how to avoid the pitfalls of songs and they should be trained on how to maximize their benefits.

(3) School administrations should be made aware of the importance of songs and they should provide more opportunities for the teachers to use them

(4) Class tests and continuous assessment has to include songs.

(5) Parents should be educated on the value of songs as effective techniques for learning English. Songs should be a constant feature in the Parents Day.

\subsection{Suggestions}

The following topics can be potential areas for further research:

(1) The ability songs to develop listening and speaking skills.

(2) The potentiality of songs to develop cultural awareness.

(3) The potentiality of songs to match the characteristics of the new generations (Alpha Gen in particular).

\section{Acknowledgements}

All the praise is due to Allah alone, who helps me finish this work. I will not forget, of course, to express my great gratitude to any person who has contributed to this research.

\section{References}

Adamowski, E. (1997). The ESL songbook. Don Mills, ON: Oxford University Press.

Ajzen, I. (1988). Attitudes, personality and behavior. Milton Keynes: Open University Press.

Atkinson, R. C., \& Shiffrin, R. M. (1968). Chapter: Human memory: A proposed system and its control processes. In K. W. Spence, \& J. T. Spence (Eds.), the Psychology of Learning and Motivation (Vol. 2, pp. 89-195). New York: Academic Press.

Baron, R. A., \& Byrne, D. (1984). Social psychology: Understanding human interaction (5th ed.). Allyn and Bacon: Massachusetts.

Basturkmen, H. (2006). Ideas and Options in English for Purposes (Mahwah, Nj: L Erlbaum Associales).

Bechtold, J. (1983). Musical ESL. TESL Talk, 14, 180-184.

Calvert, S. L., \& Tart, M. (1993). Song versus verbal forms for very-long-term, long-term, and short term verbatim recall. Journal of Applied Developmental Psychology, 14(2), 
245-260.

Domoney, L., \& Harris, S. (1993). Justified and ancient: Pop music in EFL classrooms. ELT Journal, 47, 234-241.

Eken, D. K. (1996). Ideas for using pop songs in the English language classroom. English Teaching Forum, 34, 46-47.

Gatbonton, E., \& Segalowitz, N. (1988). Creative automatization: Principles for promoting fluency within a communicative framework. TESOL Quarterly, 22, 473-492.

Griffee, D. T. (1992). Songs in action. Herfordshire, England: Phoenix ELT

Gugliemino, L. M. (1986). The affective edge: Using songs and music in ESL instruction. Adult Literacy and Basic Education, 10, 19-26

Krashen, S. D. (1983). Principles and practices in second language acquisition. Oxford, England: Pergamon Press.

Lems, K. (1996, March). Music across the ESL curriculum. Paper presented at the annual meeting of the TESOL, San Francisco, CA.

Little, J. (1983). Pop and rock music in the ESL classroom. TESL Talk, 14, 40-44.

Lo, R., \& Li, H. C. (1998). Songs Enhance Learner Involvement. English Teaching Forum, $36,8-11,21$.

Middeton, R. (1990/2002). Studying Popular Music. Philadelphia: Open University Pre.

Myers, I. B., \& Myers, P. B. (1980). Gifts differing. CA: Consulting Psychologists Press.

Peacock, M. (1997). The Effects of Authentic Materials on EFL Learners. London: Oxford University Press.

Thornbury, S. (2006). An AZ of ELT. Oxford: Macmillan Education.

Wrenshall, J. (2002). Using song to Improve Communication Competence. Bangkok: November. AUA Language Center (p. 43).

\section{Appendix}

Dear Teacher,

The following questionnaire is a part of a scientific paper about teacher's attitude towards using songs in teaching English vocabulary classes Kindly, bear in mind that your responses will be treated confidentially, and used only for this study. Your contribution is highly appreciated.

The researcher

Please choose the appropriate response for your opinion. 


\section{Macrothink}

Global Journal of Educational Studies

ISSN 2377-3936

2020, Vol. 6, No. 2

$\mathrm{SA}=$ strongly agree, $\mathrm{A}=$ Agree, $\mathrm{N}=$ Neutral, $\mathrm{DA}=$ Disagree, $\mathrm{SDA}=$ strongly disagree

Aspect 1: Teachers have positive attitude towards using songs in teaching English vocabulary classes.

\begin{tabular}{|l|l|l|l|l|l|}
\hline \multicolumn{1}{|c|}{ Item } & SA & A & N & DA & SDA \\
\hline $\begin{array}{l}\text { 1) Songs can enhance students' memories and improve their learning } \\
\text { vocabulary. }\end{array}$ & & & & \\
\hline $\begin{array}{l}\text { 2) Using songs in the classroom makes teaching and learning English } \\
\text { more interesting. }\end{array}$ & & & & \\
\hline 3) Using songs in teaching vocabulary motivates learners. & & & & \\
\hline 4) Using songs can decrease students' anxiety about English vocabulary. & & & & & \\
\hline 5) Students use new words and phrases outside classroom. & & & & \\
\hline $\begin{array}{l}\text { 6) Songs provide a large amount of repetition which results in } \\
\text { automatic use of the target language. }\end{array}$ & & & & \\
\hline 7) Students prefer songs being incorporated as a part of the lesson. & & & & & \\
\hline
\end{tabular}

Aspect 2: There are some difficulties that teachers encounter in utilizing songs in teaching English vocabulary.

8) I assume that students use the vocabulary lesson of songs after repeating them several times.

9) It is difficult to choose an appropriate song for every topic of the English vocabulary.

10) I face some difficulties in applying songs in my class.

\section{Copyright Disclaimer}

Copyright for this article is retained by the author(s), with first publication rights granted to the journal.

This is an open-access article distributed under the terms and conditions of the Creative Commons Attribution license (http://creativecommons.org/licenses/by/3.0/). 